\title{
The influence of demographic factors on perceived risks affecting attitude towards online shopping
}

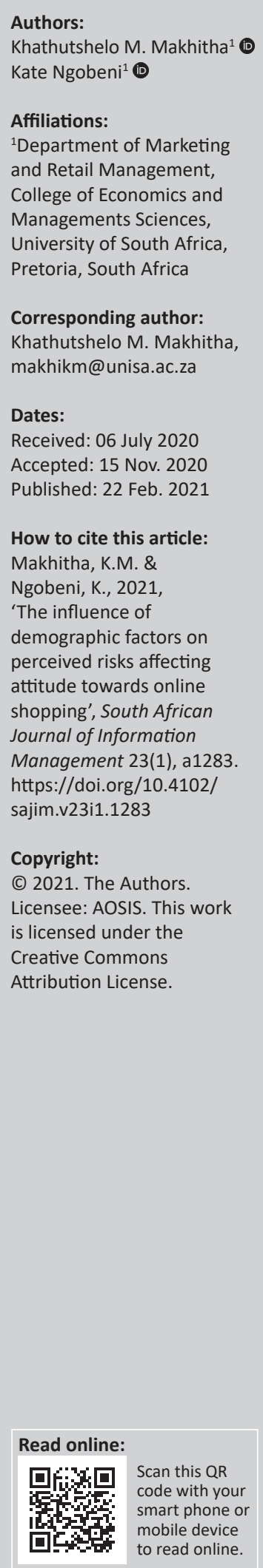

Background: Online shopping adoption has been rising in South Africa (SA). However, there is still a large majority of consumers who are not buying online because of certain risks associated with online shopping. This is despite the fact that internet adoption has increased and is widely accessible by the majority of South African consumers.

Objectives: The purpose of this study was to determine the risk factors that influence consumers' attitude towards online shopping in SA. Furthermore, the study aimed to determine whether demographic factors influence the risk factors of consumers' attitude towards online shopping in SA.

Method: A survey was conducted at two shopping malls in Gauteng, SA, targeting online consumers. A convenience sampling method was used to reach the respondents.

Results: The study found that privacy and security risks have more influence on consumers' attitude towards online shopping. Furthermore, the study found no moderating effect of gender on the relationship between risks and attitude towards online shopping. Age was found to have a moderating effect on the relationship between product, security and privacy risks and attitude towards online shopping; however, not on the relationship between product risk and attitude towards online shopping.

Conclusion: In conclusion, privacy and security risk factors have more influence on consumer attitude towards online shopping. Gender was found to have no moderating effect on the relationship between risk factors and attitude towards online shopping, whilst age had a moderating influence on relationship between privacy and security, as well as product factors and attitude towards online shopping. Marketers can address product concerns if they were to succeed online and to draw more customers to shopping online.

Keywords: online shopping; consumer behaviour; demographic factors; perceived risk; attitude; privacy and security risk; product risk; delivery risk.

\section{Introduction}

The rapid development of the internet has drastically modified the lives of consumers around the world and played an essential role in globalising and changing the consumer buying process. Online shopping is one of the technological innovations that has transformed the retail industry, by providing a platform for consumers and businesses to exchange products and services through the internet (Singh \& Rana 2018:27). Online shopping is more convenient than traditional shopping and offers consumers a wide variety of products (Tanadi, Samadi \& Gharleghi 2015:226; Tandon, Kiran \& Sah 2018:58); however, it is still perceived as riskier than shopping in traditional stores (Orubu 2016:13). The inability to physically examine the product before the purchase and the uncertainty of the aftersale service (Farhana, Khan \& Noor 2017:225; Tanadi et al. 2015:227) have altered the consumer buying process. Consumers now conduct preliminary research about products online but make the actual purchase in store because of the risks associated with purchasing online (Makhitha, Scheers \& Mogashoa 2019:313-314). The aforementioned provides evidence that consumers are willing to shop online, but the risks and uncertainty associated with online transactions create a barrier for them to complete transactions online successfully (Arora \& Sahney 2018:1045; Hsieh \& Tsao 2014:242).

Online shopping has shown exponential growth over the years, making it imperative for researchers to gain a deeper understanding on various factors that might have an impact on companies and the consumers' online buying process (Tandon et al. 2018:58). Statistics in South Africa (SA) shows that online shopping has been on the rise and that more and more consumers in SA are shopping online (eShopWorld 2017). There has been an increase in the number of online retailers in SA, including amongst others Takealot, Loot, Makro, Superbalist, OneDayOnly, Spree, 
Zando, Woolworths, Raru, NetFlorist, Mr Price, Evetech, Wootware, Yuppiechef, Incredible Connection, Dion Wired and iStore, in order of preference (MyBroadband 2017). There has also been a trend in SA where brick and mortar retailers also launch online stores and this includes retailers such as Woolworths and Mr Price. However, consumers in SA, being a developing country, still hold some concerns towards online shopping. A study by MyBroadband (2018) indicates that some South African consumers worry that they might not receive their order when items are purchased outside SA and are also concerned about difficulties regarding returns processes, as well as factors related to identity theft, fraud and security. These are risk factors that influence consumers' attitude towards online shopping.

Previous studies have identified the factors that influence online shopping behaviour (Farhana et al. 2017; Makhitha et al. 2019; Orubu 2016; Tandon et al. 2018). However, further research is needed to examine risk factors that might have an influence on consumers' attitude towards online shopping (Tandon et al. 2018:85), especially in developing countries (Bhatti, Saad \& Gbadebo 2018:8-9). Future researchers need to continue investigating the influence of additional risk factors on consumers' attitudes towards online shopping behaviour (Hong, Zulkiffli \& Hamsani 2016:20). Moreover, the influence of perceived risk and trust regarding the attitude of consumers towards online shopping intention should be tested in other contexts and categories to ensure generalisability (Marza, Idris \& Arbor 2019:594).

Existing studies that investigated risk factors influencing attitude towards online shopping were conducted in other countries (Aghekyan-Simonian et al. 2012; Ariffin, Mohan \& Goh 2018; Nawi et al. 2019). Uncovering the risk factors that influence South African consumers' attitude towards online shopping is important to gain a deeper understanding of the main perceived risk factors that influence consumers' attitude and, ultimately, their online shopping behaviour and for companies to come up with strategies to improve online revenue and gain a competitive advantage in the market (Aelita, Živilè \& Gintare 2015:301). Moreover, limited studies have investigated perceived risk factors that influence South African consumers' attitude, as well as the influence of demographic factors on perceived risk factors that influence consumers' attitudes towards online shopping.

Swiegers (2018) investigated various risks, namely perceived psychological and perceived social risk, financial risk, performance risk, time risk and physical risk in online shopping amongst Generation Y consumers in SA. Research by Makhitha et al. (2019) studied attributes influencing online shopping and identified risk as one of the factors influencing online shopping, but did not identify the type of risks. Mapande and Appiah (2018:2) also studied factors influencing consumers to shop online and included privacy and security as one of the factors. The study did not deliberate on other risk factors influencing online shopping. Therefore, it is important to investigate the risk factors and the influence of demographic characteristics on perceived risk factors that influence consumers' attitudes in an online shopping context (Tandon et al. 2018:85), as the outcomes might differ between different individuals and across countries.

Thus, this study investigates the influence of demographic factors on perceived risk factors that influence South African consumers' attitude towards online shopping.

The following research objectives were formulated for this study:

- To determine the perceived risk factors that influence consumers' attitude towards online shopping in SA.

- To determine the moderating effect of demographic factors on perceived risk factors that influence consumers' attitude towards online shopping in SA.

\section{Literature review}

Existing studies have widely adopted the theory of reasoned action (TRA) by Fishbein and Ajzen (1975), its extended theory of planned behaviour (TPB) by Ajzen (1991) and the Technology Acceptance Model (TAM) (Davis 1986) to determine consumers' attitude towards usage. According to these theories, attitude is based on an individual's positive or negative assessment of a behavioural performance. This implies that an individual who believes that performing a certain behaviour will result in positive outcomes will have a favourable attitude towards performing the behaviour, whereas an individual who believes that performing the behaviour will result in negative outcomes will have an unfavourable attitude (Nguyen et al. 2018:3). In the field of consumer behaviour, perceived risk reflects the consumer's perception that certain negative outcomes can result from the purchase of products (Pathak \& Pathak 2017:33). Based on the previous inferences, the TRA, TPB and TAM serve as strong grounding theories for the study.

\section{Online shopping in South Africa}

The South African e-commerce market consists of 19.9 million users with an additional expected growth of 4.9 million users by 2021 (Statista 2018). In 2018, the total e-commerce market value was US\$2913 million, with the electronics and media segment (books, music, games movies) being the largest contributor with a market value of US\$933 m. The total e-commerce market is expected to grow by $10.4 \%$ annually, attributed to an expected 9\% growth of user penetration by 2023 (Statista 2018). According to Export.gov (2018), online shopping in SA accounts for only $1 \%$ of the total retail sector, indicating a massive opportunity for growth.

Mobile e-commerce (M-commerce) is rapidly transforming the South African online retail sector (BusinessTech 2018) and shows potential growth encouraged by the increasing number of cellphones, improvements in internet infrastructure (Export.gov 2018; PayFast 2019) and the consumers need for convenience and enjoyment when purchasing online (Wakama, cited in IT News Africa 2017). 
There are various industries in SA that use online shopping as a transaction platform. The apparel industry is currently realising an upswing in online sales, with Zando selling 80 items a minute during Black Friday in 2017 (Du Plessis 2018), and Superbalist's total sales increasing by $80 \%$ from 2017 to 2018 on Black Friday (Gilbert 2019). Traditional brick and mortar retailers such as Mr Price, Woolworths, Truworths and the Foschini Group (TFG) have also followed the trend by investing not only into e-commerce platforms but also m-commerce platforms (Gilbert 2019).

PayFast (2019) indicated that for companies to improve their online sales and shopping platforms, latest trends such as mobility, augmented reality, personalisation, voice searches and convenient deliveries need to be taken into strategic consideration. Artificial intelligence has made it possible for companies to enhance the shopping experience by allowing consumers to virtually fit products in the comfort of their own homes, using chatbots to personalise the customer experience and voice search for customer convenience (PayFast 2019).

\section{Risk as a factor influencing online shopping risk}

Risk refers to something bad that might happen (Cambridge Dictionary). In an online shopping environment, consumers perceive certain risk associated with online shopping. Consumers are risk averse and want to maximise value from every purchase they make. However, they still perceive more risk when shopping online than in traditional brick and mortar stores (Hsieh \& Tsao 2014:241). Perceived risk refers to the perception of consumers of the uncertainty and adverse effects of engaging in a purchasing activity (Pathak \& Pathak 2017:33). The higher the perception of risk by consumers the less is their intention to shop online, which implies that perceived risks deter consumers from shopping online. Online perceived risk has been classified into six dimensions, namely financial risk, psychological risk, performance risk, time risk, social risk and privacy risk (Featherman \& Wells 2010:114). Kaur and Quareshi (2015:758) identified lack of security, absence of physical examination of products, poor quality product information and unattractive website layouts as risk factors influencing online shopping. A study investigating online shopping behaviour of Generation $\mathrm{Y}$ in Malaysia found that the perceived risk effect on online shopping was insignificant (Muda, Mohda \& Hassan 2016). Conversely, previous studies have shown that perceived risk has a significantly negative influence on online shopping (Hsieh \& Tsao 2014:241; Orubu 2016:17). Moreover, product performance risk (Farhana et al. 2017:225; Orubu 2016:14), insecurity (Farhana et al. 2017:225), delivery risk and privacy risk (Tanadi et al. 2015:226) have been identified as prevalent factors that influence consumers online shopping behaviour.

Despite the potential opportunity for growth of online shopping in SA, some consumers still have concerns regarding security and privacy whilst others worry about product deliveries (BusinessTech 2018). This leaves companies with a challenge to adapt their digital and marketing strategies and develop more innovative mobile applications to migrate consumers to mobile shopping channels (Wakama, cited in IT News Africa 2017). Therefore, this study investigates the influence of product risk (performance risk), delivery risk, privacy risk and security risk on consumers' attitude towards online shopping in SA; these risks were identified by MyBroadband (2018).

\section{Product risk}

Product risk refers to the loss felt by consumers should the product fail to meet or exceed the consumers' expectations (Tandon et al. 2018:68), which means that the product may not perform as expected (Ariff et al. 2014:1). It was defined by Tariq, Bashir and Shad (2016) as 'chances of the failure of products to meet its user's requirements'. Product risk is related to performance risk (Tariq et al. 2016:96). In an online context, product risk is caused by the consumers' inability to physically examine the product before the purchase (Farhana et al. 2017:225). According to Tariq et al. (2016:98), product risk has no significance on consumers' attitudes towards online shopping behaviour. However, Aghekyan-Simonian et al. (2012:329) found that product risk presents a significant barrier to consumers who intend on purchasing online. In a study investigating consumers' attitude towards online purchasing, Hong and Yi (2012:1304) found product risk to have a negative influence on consumers' online purchase behaviour. In addition, product risk was found to have a negative influence on consumers' attitudes towards online shopping (Ariff et al. 2014:1; Bhatti et al. 2018:7). Therefore, the following hypothesis was formulated:

H1: Product risk has a negative influence on consumers' attitudes towards shopping online.

\section{Delivery risk}

Consumers who purchase products online usually have concerns about the delivery of the product. According to Tanadi et al. (2015:227), delivery risk refers to the potential loss consumers incur from delayed delivery, non-delivery and the delivery of damaged products. Non-delivery risk was found to have a negative influence on consumers' attitudes towards online shopping (Ariff et al. 2014:1; Tariq et al. 2016:96). Furthermore, Tanadi et al. (2015:227) and Tariq et al. (2016:98) found delivery risk to have a significantly negative influence on consumers' attitudes towards purchasing online. This was supported by Nawi et al. (2019:8) who found delivery risk to have no significant impact on consumer attitudes towards online shopping. Therefore, the following hypothesis was formulated. Contrary to the given findings, Hong et al. (2016:18) found a significant effect of delivery risk towards customer attitude in online shopping, which implies that the impact that delivery risk has on attitude towards online shopping differs across consumer groups: 
H2: Delivery risk has a negative influence on consumers attitudes towards shopping online.

\section{Privacy and security risk}

According to Dai and Chen (2015:46), consumers' personal and financial information can be put in a great danger because of security breaches, which result in consumers suffering identity theft and financial loss. Consumers who shop online develop a certain level of vulnerability from using online payment systems and authenticating the reliability of privacy policies (Tanadi et al. 2015:228). Security and privacy risk have been found to be the most prominent factors that influence consumers' online purchasing decision (Hong \& Yi 2012:1305) and that consumers with a stronger privacy and security concerns would not shop online (Schlosser, White \& Llyod 2006:137). The risk is associated with consumers' fear of the misuse of personal and financial information (Thakur \& Srivastava 2015:153). Privacy risk in an online context refers to the potential loss of confidential information and exposure to identity theft (Featherman \& Wells 2010:114), whereas security risk refers to concerns about monetary loss through using online payment systems (Thakur \& Srivastava 2015:153). Privacy risk has been found as one of the factors that deters consumers from successfully completing online purchases that only require online payment methods (Hong \& Yi 2012:1305). Moreover, Orubu (2016:17) found privacy risk to have significantly negative influence on consumers' attitudes towards online shopping behaviour.

Security still remains a barrier for consumers to shop online (Rahman et al. 2018:2). Consumers' issues are centred around concerns of secure payment systems, as most of them believe that online payment systems are not safe (Yadav, Sharma \& Tarhini 2016:2,18). This is consistent with Dai and Chen's (2015:41) findings that security concern negatively influences consumers' purchase intentions on online shopping platforms. Therefore, the following hypothesis was formulated:

H3: Privacy and security risk has a negative influence on consumers' attitudes towards shopping online.

\section{Demographic influence on risk factors influencing online buying behaviour}

Demographics tend to have a significant effect on consumers' perceived risk towards online platforms. According to Marriott and Williams (2018:20), financial risk significantly influences male and female consumers' intention to purchase online. Pascual-Miguel, Agudo-Peregrina and ChaparroPeláez (2015:1554) found that women perceive more risk when they have the intention to shop online. However, Lin et al. (2018:1195) found that perceived risk has a higher negative influence on male consumers' attitude towards online shopping, especially performance risk (Marriott \& Williams 2018:26). Moreover, female consumers were found to have a higher positive attitude towards the financial security of online shopping platforms $(\mathrm{Wu}$, Quyen \& Rivas
2016:706). Pascual-Miguel et al. (2015:1554) stated the gender difference is narrowing in the adoption of online shopping behaviour. It is thus important to further investigate the influence of gender on the risk factors affecting online buying behaviour.

The influence of consumers' age on the risk factors affecting online buying behaviour is important for retailers to develop sustainable strategies. According to Singh and Rana (2018:32), age has no influence on consumers' perceptions towards adopting online shopping. In Marriott and Williams (2018:14) study investigating the moderating effect of age on perceived risk towards online shopping, age was found to have a significant influence on consumers' adoption of online shopping. However, performance risk and time risk were found to have no significant influence on young and old consumers' intention to shop online (Marriott \& Williams 2018:14). Thus, the following hypotheses were formulated:

H4: Gender has a moderating influence on consumers' product risk towards online shopping.

H5: Gender has a moderating influence on consumers' delivery risk towards online shopping.

H6: Gender has a moderating influence on consumers' privacy and security risk towards online shopping.

H7: Age has a moderating influence on consumers' product risk towards online shopping.

H8: Age has a moderating influence on consumers' delivery risk towards online shopping.

H9: Age has a moderating influence on consumers' privacy and security risk towards online shopping.

\section{Research methodology Study design}

In order to achieve the objectives of this study, a survey research method was deemed appropriate to test the hypotheses as shown in Figure 1. Similarly, prior studies on online shopping adopted a survey method to determine risk factors influencing consumer attitude towards online shopping. A survey requires a respondent to choose a response from those provided and allows a researcher to

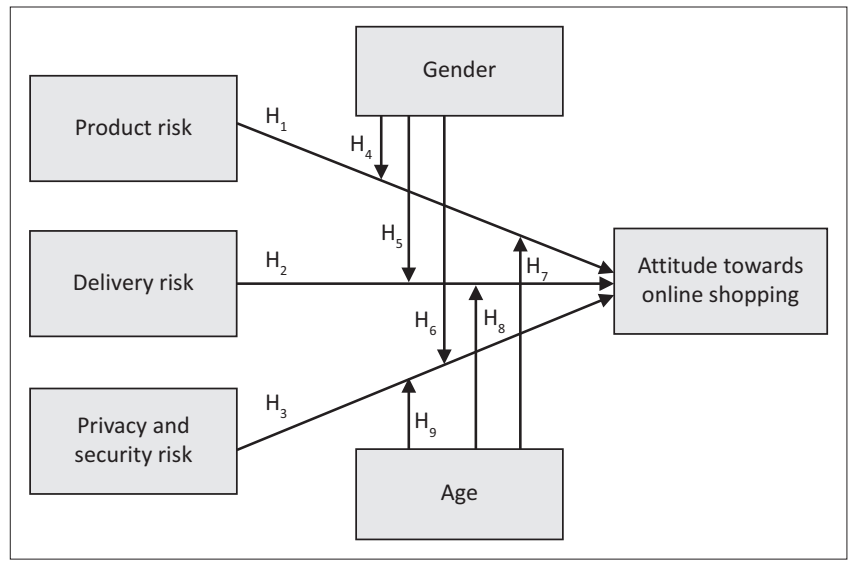

$\mathrm{H}$, hypothesis.

FIGURE 1: Perceived risks model. 
compare responses. It was appropriate for this research to determine the risks influencing consumer attitude towards online shopping and to determine the moderating influence of demographic factors on risk influencing consumer attitude towards online shopping.

\section{The population of the study and sample design}

The target population for the present research comprised of retail consumers in SA who shops at the two malls: Cresta mall in Johannesburg and Sunny Park mall in Sunnyside, Pretoria. These shoppers must have access to the internet and have either shopped online or intend to shop online. The researchers were given permission by the shopping mall managers to intercept any consumers between the age of 10 and 65 , visiting the malls at the time of data collection. The questionnaires were completed by 207 shoppers who visited the mall at the time of study. Participants were made aware that participating in the study was voluntary. Convenience sampling was used and fieldworkers were used to hand out questionnaires in the two malls. Convenience sampling was considered appropriate for the study because shoppers who visited the malls at the time of data collection were intercepted when entering the malls. Using convenience sampling made it possible to have easy access, obtaining respondents quicker and cheaper (Wiid \& Diggines 2013). The two malls also have high congestion, which supports the adoption of a convenience sampling method. Of the 210 targeted users, 207 responded, culminating in a response rate of $98 \%$, which is a high response rate.

\section{Questionnaire construction}

The questionnaire was developed using the scales of prior research studies: Product risk (Aghekyan-Simonian et al. 2012; Ariffin et al. 2018; Hsieh \& Tsao 2014; Javadi et al. 2012; Tandon et al. 2018; Tariq et al. 2016; Thakur \& Srivastava 2015; Vijayasarathy 2004), privacy and security risk (Ariffin et al. 2018; Hsieh \& Tsao 2014; Thakur \& Srivastava 2015) and delivery risk (Hong \& Yi 2012; Javadi et al. 2012; Tandon et al. 2018; Tariq et al. 2016). The study focused on two demographic factors: gender and age; however, additional 11 demographic questions were included in the questionnaire for the purpose of understanding the respondents better. In addition, 21 statements of the questionnaire covered risk factors influencing consumer attitude towards online shopping. The consumers were asked to rate each of the risk factors on a Likert scale from one to five, with one measuring 'highly disagree' and five measuring 'highly agree'. The five-point Likert scale is the most commonly used and was deemed appropriate for this study to determine the risk factors influencing consumer attitude towards online shopping.

\section{Data collection and data analysis}

Data were collected from the two malls from March 2019 to April 2019. Shoppers who visited the mall during this period were intercepted by field workers and were asked to participate in the study. Respondents were made aware that completion of the questionnaire was voluntary and that no compensation would be offered to consumers who completed the questionnaire that was ethically approved by the academic institution. Two hundred and seven questionnaires were completed for the study.

The data were analysed with the aid of international business machine (IBM) statistical package for the social sciences (SPSS) for Windows, version 25. Various statistical analyses were conducted to achieve the objectives of this study, including descriptive analyses, such as mean and standard deviation, factor analysis, analysis of variance (ANOVA) and regression analysis.

\section{Ethical considerations}

The study received ethical clearance from the Department of Marketing and Retail Management Ethics Review Committee on 15 February 2019 with reference number: 2019_MRM_001.

\section{Results and findings Descriptive stats}

As shown in Table 1, respondents consisted of more females $(60.4 \%, n=125)$ than males $(39.6 \%, n=82)$. Almost one-third of the respondents were aged $18-21$ years $(31.6 \%, n=65)$, followed by $22-25$ years $(28.5 \%, n=59)$. The $22-25$ years were represented by $19 \%$ of the respondents $(n=40)$, whilst the 31-35 years was represented by $13 \%$ of the respondents $(n=17)$. Those over 36 were less represented with 15 respondents representing $7 \%$ of the population.

All respondents $(100 \%, n=207)$ had access to the internet. More than $90 \%(93.7 \%, n=194)$ of the respondents use their cell phones to access the internet. The next more popular method for connecting to the internet is from a computer at home $(45.9 \%, n=95)$. More than $70 \%(72.8 \%, n=150)$ of the respondents use the internet for communication, social websites and others. The next more popular reason for accessing the internet is finding information (57.3\%, $n=118)$, followed by research, homework and study $(48.1 \%, n=99)$.

\begin{tabular}{lccc} 
TABLE 1: Demographics of respondents. & & \\
\hline Demographics & Variable & $\boldsymbol{N}$ & $\mathbf{\%}$ \\
\hline Gender & Male & 82 & 40 \\
& Female & 125 & 60 \\
& Total & 207 & 100 \\
Age (years) & $18-21$ & 65 & 31 \\
& $22-25$ & 59 & 29 \\
& $26-30$ & 40 & 19 \\
& $31-35$ & 27 & 13 \\
& $36-45$ & 13 & 6 \\
& $46-54$ & 1 & 1 \\
& $55-60$ & 1 & 1 \\
& Total & 206 & 100 \\
\hline
\end{tabular}


The majority of the respondents $(83.1 \%, n=172)$ possess a bank card and buy clothing and accessories online $(61.1 \%, n$ $=118$ ). The next most popular type of purchase is books (32.6\%, $n=63)$, followed by electronic goods $(30.6 \%, n=59)$. Almost $60 \%(58.5 \%, n=121)$ of the respondents do not buy electronic products online. Of those respondents who do not buy electronic goods online, almost one third $(32.5 \%, n=40)$ indicated that they may buy electronic goods online in the next 12 months. Of those respondents who currently buy electronic goods online, more than $40 \%(43.2, n=38)$ do so once a year. Of those respondents who buy electronic goods online, $36.8 \%(n=75)$ visit one to three online stores before making the purchase.

The most popular online shop to purchase electronic goods from is Takealot $(70.4 \%, n=119)$, followed by Makro $(38.5 \%, n=65)$.

\section{Factor analysis}

Principal component analysis (PCA) with IBM SPSS Statistics 26 was used to examine patterns of correlations amongst the questions used to assess the respondents' perceptions regarding the consumer risk of online buying in SA.

The factorability of the correlation matrix was investigated using Pearson's product-moment correlation coefficient. Preliminary distribution analyses indicated that the assumptions of normality, linearity and homoscedasticity were not violated. The correlation matrix (Table 2) demonstrated some of coefficients of 0.3 and above. The Kaiser-Meyer-Olkin value was 0.825, well above the recommended minimum value of 0.6 (Kaiser 1970, 1974) and the Bartlett's test of sphericity (Bartlett 1954) reached statistical significance, $p<0.001$. Thus, the correlation matrix was deemed factorable.

Twenty-one items were initially subjected to PCA and this resulted in a four-factor solution that explained $61.515 \%$ of the variance in the data. Six of the variables had to be excluded because they were not contributing to the solution. The remaining 15 items resulted in a three-factor solution explaining $59.864 \%$ (Table 2) of the variation in the data.

As is visible from Table 3, the Cronbach's alpha for the three factors ranged from 0.736 to 0.877 , which is satisfactory because they are over 0.70. The overall Cronbach's alpha was 0.713 , also higher than 0.70 recommended by Malhotra (2010). To determine the validity of the instrument,

TABLE 2: Correlation amongst the factors.

\begin{tabular}{|c|c|c|c|c|}
\hline Variable & $\begin{array}{l}\text { Delivery } \\
\text { factors }\end{array}$ & $\begin{array}{c}\text { Privacy and } \\
\text { security factors }\end{array}$ & $\begin{array}{l}\text { Product } \\
\text { factors }\end{array}$ & $\begin{array}{l}\text { Attitude towards } \\
\text { online shopping }\end{array}$ \\
\hline Delivery factors & 1 & - & - & - \\
\hline $\begin{array}{l}\text { Privacy and security } \\
\text { factors }\end{array}$ & $-0.166 *$ & 1 & - & - \\
\hline Product factors & $0.396 * *$ & $-0.156^{*}$ & 1 & - \\
\hline $\begin{array}{l}\text { Attitude towards } \\
\text { online shopping }\end{array}$ & 00.011 & $0.510 * *$ & $-0.163 *$ & 1 \\
\hline
\end{tabular}

*, Correlation is significant at the 0.05 level (2-tailed); **, Correlation is significant at the 0.01 level (2-tailed). the threshold of $0.490-0.740$, was maintained on the communalities, as well as a cut-off point of 0.30 on the Pearson's correlations, as suggested by Kim and Mueller (1978). Product risk loaded six items whilst privacy and security loaded five item and delivery risks loaded four items. The mean scores for the factors were 2.135, 2.735 and 3.051 , respectively, which means that the respondent agreed more on product factors impacting on attitude towards online factors followed by privacy and security factors and delivery factors, respectively.

\section{Testing hypotheses}

To establish the effect of the predictors on attitude towards online shopping, multiple ordinary least squares (OLS) regression was used, with the Enter method for adding predictors. As shown in Table 4 and Table 5, the model is significant $(F[7]=12.424, p<0.001)$, meaning that at least one of the predictors has a significant relationship with attitude towards online shopping. From the adjusted $R$-square value of 0.282 , the model explains at least $28 \%$ of the variation in attitude towards online shopping.

Collinearity statistics (Table 6) indicate that multicollinearity among predictors is not a problem (VIF < 10). The only predictors that are significant in the model, however marginal, are product factors (0.031), privacy and security

TABLE 3: Factor analysis.

\begin{tabular}{|c|c|c|c|}
\hline Risk factors & $\begin{array}{l}\text { Product } \\
\text { risk }\end{array}$ & $\begin{array}{l}\text { Privacy and } \\
\text { security }\end{array}$ & $\begin{array}{l}\text { Delivery } \\
\text { risk }\end{array}$ \\
\hline $\begin{array}{l}\text { There is a risk of the product not being the } \\
\text { same as advertised. }\end{array}$ & 0.849 & - & - \\
\hline $\begin{array}{l}\text { When shopping online, there is a risk of the } \\
\text { product malfunctioning when delivered. }\end{array}$ & 0.833 & - & - \\
\hline $\begin{array}{l}\text { There is a risk of me not being happy with } \\
\text { my purchase once it arrives. }\end{array}$ & 0.805 & - & - \\
\hline $\begin{array}{l}\text { Online shopping is risky because I cannot } \\
\text { examine the product. }\end{array}$ & 0.752 & - & - \\
\hline $\begin{array}{l}\text { I might not receive the exact specified quality } \\
\text { of a product that I purchased. }\end{array}$ & 0.689 & - & - \\
\hline The product description might be incorrect. & 0.655 & - & - \\
\hline I trust online shops. & - & 0.771 & - \\
\hline $\begin{array}{l}\text { I feel safe to use my bank card when shopping } \\
\text { online. }\end{array}$ & - & 0.735 & - \\
\hline $\begin{array}{l}\text { I am comfortable with providing my personal } \\
\text { information when shopping online. }\end{array}$ & - & 0.732 & - \\
\hline $\begin{array}{l}\text { I use shopping sites that have adequate data } \\
\text { protection technology (e.g. data encryption) } \\
\text { for secure online transactions. }\end{array}$ & - & 0.697 & - \\
\hline $\begin{array}{l}\text { Policies related to product purchases and } \\
\text { returns are stated on the online websites. }\end{array}$ & - & 0.676 & - \\
\hline $\begin{array}{l}\text { Online shopping may affect the image of the } \\
\text { people around me. }\end{array}$ & - & - & 0.818 \\
\hline $\begin{array}{l}\text { The purchased product may result in } \\
\text { disapproval from my family. }\end{array}$ & - & - & 0.759 \\
\hline $\begin{array}{l}\text { Finding the right product through online } \\
\text { shopping is difficult. }\end{array}$ & - & - & 0.717 \\
\hline $\begin{array}{l}\text { I fear that the apparel will not be delivered } \\
\text { appropriately. }\end{array}$ & - & - & 0.471 \\
\hline Cronbach's alpha: 0.713 & 0.877 & 0.769 & 0.735 \\
\hline Mean scores & 2.135 & 2.758 & 3.051 \\
\hline Standard deviation & 0.848 & 0.829 & 0.880 \\
\hline$\%$ of variance & 32 & 16 & 12 \\
\hline Eigen values & 4.709 & 2.451 & 1.819 \\
\hline Cumulative percentage & 31 & 48 & 60 \\
\hline
\end{tabular}


factors (0.000) and age (0.033) with levels of significance lower than 0.05. According to Tabachinik and Fidell (2001:32), a hypothesis with a significance level below 0.05 should be accepted.

The only predictors that are significant in the model are product factors, privacy and security factors, and age. The constant in the linear equation is also significant. Gender has no moderating effect on the relationship between risk factors and attitude towards online shopping. However, age has the moderating effect on the relationship between product factors, privacy and security factors and attitude towards online shopping. The privacy and security factors have a stronger effect on attitude towards online shopping with a beta coefficient of 0.508 compared to -0.143 for products effects, which is both lower and negative. Existing findings reported contradicting results with Dai and Chen (2012) supporting the findings of this study, while Nawi et al. (2019) findings do not support the findings of this study. AghekyanSimonian et al. (2012) support this study's findings that product influences consumers' attitudes towards online shopping. Thakur and Srivastava (2015) found that security and privacy risk weigh relatively lower as compared to product performance risk, which also contract this study's findings.

The above findings indicate that there is no influence of gender towards risk factors influencing attitude on online shopping. The results are supported by Makhitha et al. (2019) who found that gender has no influence towards online shopping. Other studies on online shopping also did not find a significant impact of gender towards online shopping (Brashear et al. 2010; Chiu, Lin \& Tang 2005). However, some

\begin{tabular}{lcccc}
\multicolumn{2}{l}{ TABLE 4: Regression analysis: Risk factors. $\dagger$} \\
\hline Model & $\boldsymbol{R}$ & $\boldsymbol{R}^{2}$ & Adjusted $\boldsymbol{R}^{2}$ & $\begin{array}{c}\text { Std. error of } \\
\text { the estimate }\end{array}$ \\
\hline 1 & $0.553 \$$ & 0.306 & 0.282 & 0.659 \\
\hline
\end{tabular}

$\dagger$, Dependent variable: Attitude towards online shopping; $\$$, Predictors: (Constant), C124 What is your gender? Male, delivery factors, privacy and security factors, product factors, C125_rec How old are you?

TABLE 5: ANOVA: Risk and demographic factors. $\dagger$

\begin{tabular}{llccccc}
\hline Model & Variable & Sum of squares & $d f$ & Mean square & $\boldsymbol{F}$ & Sig. \\
\hline 1 & Regression & 37.866 & 7 & 5.409 & 12.424 & $0.000 \%$ \\
& Residual & 85.772 & 197 & 0.435 & - & - \\
& Total & 123.638 & 204 & - & - & - \\
\hline
\end{tabular}

$\dagger$, Dependent variable: Attitude towards online shopping; $\$$, Predictors: (Constant), C124 What is your gender? Male, delivery factors, privacy and security factors, product factors, W125_rec How old are you? studies such as those of Slyke, Comunale and Belanger (2002) and Venkatesh and Morris (2000) found online shopping behaviour to vary across gender of consumers.

Existing studies also reported conflicting findings with some reporting age to have influence towards online shipping (Makhitha 2014; Makhitha et al. 2019; Rudansky-Kloppers 2016), while others reported that age has no influence towards online shopping (Kim 2006).

\section{Recommendations and conclusions}

From the given results, privacy and security has more influence towards online shopping than other risk factors. Therefore, marketers must address privacy and security if they were to succeed online and to draw more customers to shopping online. Consumers are concerned about the safety of bank cards and providing personal information when shopping online. They also want secure online transactions. This could be addressed by protecting consumers' personal details. They can make use of safe online payment systems, which will reduce the fear of shopping online. Marketers could also address fraud and theft issues and any other privacy and security concerns and communicate these to consumers using various communication platforms. In addition, they can ensure that online retail shops have adequate security, trustworthiness of information and privacy (Rudansky-Kloppers 2016).

To address the delivery risk, marketers must ensure that they deliver the product as ordered. Should it happen that they deliver the wrong product, they must exchange the product without customers incurring any costs.

The study further found that gender does not moderate product risk, privacy and security risks and delivery risks. This implies that the extent to which risks influence online shopping does not differ across gender of online shoppers. Therefore, marketers should address risk factors across all gender and not to any specific gender.

The results of this study revealed that age has a potential moderating effect on the relationship between privacy and security factors and attitude towards online shopping. The results further demonstrated that age has a potential moderating effect on the relationship between product factors and attitude towards online shopping. This implies that marketers of online shops should address the online

TABLE 6: Collinearity statistics: Coefficients. $\dagger$

\begin{tabular}{|c|c|c|c|c|c|c|c|c|}
\hline \multirow{2}{*}{\multicolumn{2}{|c|}{ Model }} & \multicolumn{2}{|c|}{ Unstandardised coefficients } & \multirow{2}{*}{$\begin{array}{c}\text { Standardised } \\
\text { coefficients: Beta }\end{array}$} & \multirow[t]{2}{*}{$t$} & \multirow[t]{2}{*}{ Sig. } & \multicolumn{2}{|c|}{ Collinearity statistics } \\
\hline & & B & Std. error & & & & Tolerance & VIF \\
\hline \multirow[t]{5}{*}{1} & (Constant) & 0.723 & 0.314 & - & 2.302 & 0.022 & - & - \\
\hline & Delivery factors & 0.116 & 0.062 & 0.126 & 1.883 & 0.061 & 0.783 & 1.277 \\
\hline & Product factors & -0.127 & 0.058 & -0.143 & -2.175 & 0.031 & 0.811 & 1.233 \\
\hline & Privacy and security factors & 0.476 & 0.057 & 0.508 & 8.308 & 0.000 & 0.943 & 1.060 \\
\hline & C124 What is your gender? Male & 0.049 & 0.096 & 0.031 & 0.509 & 0.612 & 0.954 & 1.049 \\
\hline
\end{tabular}

$t$, $t$-value; Sig, significant; B, unstandardized Beta; Std., standard; VIF, variance inflation factor.

$\dagger$, Dependent variable: Attitude towards online shopping. 
shopping risk targeted people of different age groups. This implies that shoppers at different age groups perceive risk factors in online shopping differently and their concerns should be addressed differently by online marketers.

In conclusion, privacy and security factors were found to have more effect on attitude towards online shopping than product factors. The delivery risk factors do not influence attitude towards online shopping. Consumers of different genders did not differ in their attitude towards online shopping. However, consumers of different age groups were found to have different attitudes towards online shopping.

The study targeted consumers in Pretoria and Johannesburg malls. The findings of this study should not be generalised and do not reflect perceptions of consumers in other provinces in SA. Further studies could be conducted on the use of augmented reality in online shopping to determine if they would not reduce the risks in online shopping. Future studies could also investigate different product categories - for example, low and high involvement products.

\section{Acknowledgements}

The authors would like to acknowledge A. Nhlapulo, for giving access to her master's dissertation data, which have been used for this study. The data used here were not analysed for her study, and they are by no means a replication of what she wrote in her dissertation.

\section{Competing interests}

The authors declare that they have no financial or personal relationships that may have inappropriately influenced them in writing this research article.

\section{Authors' contributions}

K.M.M. completed the research methodology and empirical part of the article. K.N. wrote the literature section of the article.

\section{Funding information}

This research received no specific grant from any funding agency in the public, commercial or not-for-profit sectors.

\section{Data availability}

The data that support the findings of this study are available from the corresponding author, K.M.M., upon reasonable request.

\section{Disclaimer}

The views and opinions expressed in this article are those of the authors and do not necessarily reflect the official policy or position of any affiliated agency of the authors.

\section{References}

Aelita, S., Živilè, G. \& Gintarè, G., 2015, 'Factors influencing consumers online shopping decision: Present and future evidence from Lithuania', Social Technologies 5(1), 301-311.

Aghekyan-Simonian, M., Forsythe, S., Kwon, W.S. \& Chattaraman, V., 2012, 'The role of product brand image and online store image on perceived risks and online purchase intentions for apparel', Journal of Retailing and Consumer Services 19(3), 325-331. https://doi.org/10.1016/j.jretconser.2012.03.006

Ajzen, I., 1991, 'The theory of planned behavior', Organizational Behavior and Human Decision Processes 50(2), 179-211. https://doi.org/10.1016/07495978(91)90020-T

Ariff, M.S.M., Sylvester, M., Zakuan, N., Ismail, K. \& Ali, K.M., 2014, 'Consumer perceived risk, attitude and online shopping behaviour: Empirical evidence from Malaysia', Paper presented at the IOP Conference Series: Materials Science and Engineering, vol. 58, no. 1, p. 012007, Jakarta, Indonesia, June 2014, IOP Publishing.

Ariffin, S.K., Mohan, T. \& Goh, Y., 2018, 'Influence of consumers' perceived risk on consumers' online purchase intention', Journal of Research in Interactive Marketing 12(3), 309-327. https://doi.org/10.1108/JRIM-11-2017-0100

Arora, S. \& Sahney, S., 2018, 'Consumer's webrooming conduct: An explanation using the theory of planned behaviour', Asia Pacific Journal of Marketing and Logistics 30(4), 1040-1063.

Bartlett, M.S., 1954, 'A note on the multiplying factors for various chi square approximations', Journal of the Royal Statistical Society (Series B) 16(2), 296-298. https://doi.org/10.1111/j.2517-6161.1954.tb00174.x

Bhatti, A., Saad, S. \& Gbadebo, S.M., 2018, 'Convenience risk, product risk, and perceived risk influence on online shopping: Moderating effect of attitude', Science Arena Publications International Journal of Business Management 3(2), 1-11.

Brashear, T., Kashyap, V., Musante, M. \& Donthu, N., 2010, 'A profile of the Internet shopper: evidence from six countries', Journal of Marketing Theory and Practice 17(3), 267-289.

BusinessTech, 2018, South Africans are expected to spend R45 billion shopping online this year, viewed 20 December 2019, from https://businesstech.co.za/news/ internet/269645/south-africans-are-expected-to-spend-r45-billion-shoppingonline-this-year.

Chiu, Y.B., Lin, C.P. \& Tang, L.L., 2005, 'Gender differs: Assessing a model of online purchase intentions in e-tail services', International Journal of Service Industry Management 16(5), 419-435.

Dai, H. \& Chen, Y., 2015, 'Effects of exchange benefits, security concerns and situational privacy concerns on mobile commerce adoption', Journal of International Technology and Information Management 24(3), 41-56.

Davis, F.D., 1989, 'Perceived usefulness, perceived ease of use, and user acceptance of information technology', MIS Quarterly 13(3), 319-340.

Du Plessis, G., 2018, \#MobileCommerce: The growth of mobile shopping in South Africa, viewed 09 December 2019, from https://www.bizcommunity.com/ Article/196/822/179452.html.

eShopWorld, 2017, South Africa eCommerce insights / 24.79 million online shoppers by 2021, viewed 29 December 2019, from http://www.eshopworld.com/blogarticles/south-africa-ecommerce-insights.

Export.gov., 2018, South Africa - ECommerce / Export. gov., viewed 19 December 2019, from https://www.export.gov/article?id=South-Africa-ecommerce.

Farhana, N., Khan, T. \& Noor, S., 2017, 'Factors affecting the attitude towards online shopping: An empirical study on urban youth in Bangladesh', Australian Academy of Business and Economics Review 3(4), 224-234.

Featherman, M.S. \& Wells, J.D., 2010, 'The intangibility of e-services: Effects on perceived risk and acceptance', The Data Base for Advances in Information Systems: A Quarterly Publication of SIGBIT 41(2), 110-131. https://doi.org/ 10.1145/1795377.1795384

Fishbein, M. \& Ajzen, I., 1975, Belief attitude, intention and behavior: An introduction to theory and research, Addison-Wesley, Reading, MA.

Gilbert, P., 2019, Clothing retailers see more online growth, viewed 20 December 2019, from https://www.itweb.co.za/content/IwrKxq3JLdRMmg1o.

Hong, L.M., Zulkiffli, W.F.W. \& Hamsani, N.H., 2016, 'The impact of perceived risks towards customer attitude in online shopping', International Journal of Accounting, Finance and Business 1(2), 13-21.

Hong, Z. \& Yi, L., 2012, 'Research on the influence of perceived risk in consumer online purchasing decision', Physics Procedia 24(B), 1304-1310. https://doi.org/ 10.1016/j.phpro.2012.02.195

Hsieh, M. \& Tsao, W., 2014, 'Reducing perceived online shopping risk to enhance loyalty: Website quality perspective', Journal of Risk Research 17(2), 241-261. https://doi.org/10.1080/13669877.2013.794152

Javadi, M.H.M., Dolatabadi, H.R., Nourbakhsh1, M., Poursaeedi, A. \& Asadollahi, A.R., 2012 , 'An analysis of factors affecting on online shopping behavior of consumers', International Journal of Marketing Studies 4(5), 81-98. https://doi.org/10.5539/ ijms.v4n5p81

Kaiser, H.F., 1970, 'A second-generation little jiffy', Psychometrica 35, 410-415. https://doi.org/10.1007/BF02291817

Kaiser, H.F., 1974, 'An index of factorial simplicity', Psychometrica 39, 31-36. https:// doi.org/10.1007/BF02291575 
Kaur, G. \& Quareshi, T.K., 2015, 'Factors obstructing intentions to trust and purchase products online', Asia Pacific Journal of Marketing and Logistics 27(5), 758-783. hrttps://doi.org/10.1108/APJML-10-2014-0146

Kim, J.O. \& Mueller, C.W., 1978, Factor analysis: Statistical methods and practical issues: Computer Science, Sage Publications, Beverly Hills, CA.

Kim, S., 2006, 'Using hedonic and utilitarian shopping motivations to profile inner city consumers', Journal of Shopping Centre Research 13(1), 57-79.

Lin, X., Featherman, M., Brooks, S.L. \& Hajli, N., 2018, 'Exploring gender differences in online consumer purchase decision making: An online product presentation perspective', Information Systems Frontiers 21, 1187-1201. https://doi.org/ 10.1007/s10796-018-9831-1

Makhitha, K.M., 2014, 'Factors influencing Generations Y students' attitude towards online shopping', Mediterranean Journal of Social Sciences 5(21), 39-50.

Makhitha, K., Scheers, L. \& Mogashoa, C., 2019, 'Which consumer attributes influence South African consumers to shop online', Journal of Business \& Retail
Management Research 13(4), 312-325. https://doi.org/10.24052/JBRMR/ Management $R$ R
V13IS04/ART-29

Malhotra, N.K., 2010, Marketing research: An applied orientation, 6th edn., Pearson Prentice-Hall, Upper Saddle River, NJ.

Mapande, F.V. \& Appiah, M., 2018, 'The factors influencing customers to conduct online shopping: South African Perspective', 2018 International Conference on Intelligent and Innovative Computing Applications (ICONIC), Mon Trésor, Mauritius, December 06-07, 2018, pp. 1-5.

Marriott, H.R. \& Williams, M.D., 2018, 'Exploring consumers perceived risk and trus for mobile shopping: A theoretical framework and empirical study', Journal of Retailing Consumer Services 42, 133-146. https://doi.org/10.1016/j. jretconser.2018.01.017

Marza, S., Idris, I. \& Abror, A., 2019, 'The influence of convenience, enjoyment, perceived risk, and trust on the attitude toward online shopping', Proceedings of the 2nd Padang International Conference on Education, Economics, Business and Accounting (PICEEBA-2 2018), Advances in Economics, Business and Management Research 64, pp. 588-597 Atlantis Press, n.l.

Muda, M., Mohd, R. \& Hassan, S., 2016, 'Online purchase behavior of generation Y in Malaysia', Procedia Economics and Finance 37(16), 292-298. https://doi. org/10.1016/S2212-5671(16)30127-7

MyBroadband, 2017, Biggest online shops in South Africa, viewed 07 January 2021 from https://mybroadband.co.za/news/business/207168-biggest-online-shopsin-south-africa.html.

MyBroadband, 2018, How long South Africans wait for their online deliveries to arrive viewed 07 January 2021, from https://mybroadband.co.za/news/business/ 287526-how-long-south-africans-wait-for-their-online-deliveries-to-arrive.html.

Nawi, N.C., Mamun, A.A., Binti Hamsani, N.H. \& Muhayiddin, M.N., 2019, 'Effect of consumer demographics and risk factors on online purchase behaviour in Malaysia', Societies 9(1), 1-11. https://doi.org/10.3390/soc9010010

Nguyen, Q.A., Hens, L., MacAlister, C., Johnson, L., Lebel, B., Tan, S.B. et al., 2018, 'Theory of reasoned action as a framework for communicating climate risk: A case study of schoolchildren in the Mekong Delta in Vietnam', Sustainability 10(6), 1-14. https://doi.org/10.3390/su10062019

Orubu, O.F., 2016, 'The impact of perceived risk on willingness to buy in online markets', E3 Journal of Business Management and Economics 7(1), 13-18. https:// doi.org/10.18685/EJBME(7)1_EJBME-15-020

Pascual-Miguel, F.J., Agudo-Peregrina, Á.F. \& Chaparro-Peláez, J., 2015, 'Influences of gender and product type on online purchasing', Journal of Business Research 68(7), 1550-1556. https://doi.org/10.1016/j.jbusres.2015.01.050

Pathak, V.K. \& Pathak, A., 2017, 'Understanding perceived risk: A case study of green electronic consumer products', Management Insight 13(1), 33-37. https://doi. org/10.21844/mijia.v13i01.8367
PayFast, 2019, How to take advantage of 2019 ecommerce trends, viewed 18 December 2019, from https://www payfast.co.za/blog/how-to-take-advantage-of2019-e-commerce-trends/.

Rahman, M.A., Islam, M.A., Esha, B.H., Sultana, N., Chakravorty, S. \& Molnar, A., 2018, 'Consumer buying behavior towards online shopping: An empirical study on Dhaka City, Bangladesh', Cogent Business \& Management 5(1), 1-22. https://doi. org/10.1080/23311975.2018.1514940

Rudansky-Kloppers, S., 2016, 'Key factors influencing the online buying decision when purchasing products in specific product categories', African Journal of Science, Technology, Innovation and Development 9(1), 43-45.

Schlosser, A.E., White, T.B. \& Lloyd, S.M., 2006, 'Converting web site visitors into buyers: How web site investment increases consumer trusting beliefs and online purchase intentions', Journal of Marketing 70(2), 133-148. https://doi. org/10.1509/jmkg.70.2.133

Singh, S. \& Rana, R., 2018, 'Effect of demographic factors on consumers' perception of online shopping', Global Journal of Management and Business Research 18(6), 27-38.

Slyke, C., Comunale, C.L. \& Belanger, F., 2002, 'Gender differences in perceptions of web-based shopping', Communications of the ACM 45(7), 82-86.

Statista, 2018, eCommerce, viewed 19 December 2019, from https://www.statista. com/outlook/243/112/ecommerce/south-africa.

Swiegers, L., 2018, 'Perceived risk barriers to online shopping: Experiences of technologically enabled Generation Y consumers', Doctoral dissertation, Stellenbosch University.

Tabachinik, B.G. \& Fidell, L.S., 2001, Using multivariate statistics, 4th edn., International student edn., Allyn and Bacon, Needham Heights, MA.

Tanadi, T., Samadi, B. \& Gharleghi, B., 2015, 'The impact of perceived risks and perceived benefits to improve an online intention among generation- $Y$ in Malaysia', Asian Social Science 11(26), 226-238. https://doi.org/10.5539/ass.v11n26p226

Tandon, U., Kiran, R. \& Sah, A., 2018, 'The influence of website functionality, drivers and perceived risk on customer satisfaction in online shopping: An emerging economy case', Information Systems \& e-Business Management 16(1), 57-91. https://doi.org/10.1007/s10257-017-0341-3

Tariq, A., Bashir, B. \& Shad, M.A., 2016, 'Factors affecting online shopping behavior of consumers in Pakistan', Journal of Marketing and Consumer Research 19 (2016), 95-100.

Thakur, R. \& Srivastava, M., 2015, 'A study on the impact of consumer risk perception and innovativeness on online shopping in India', International Journal of Retail \& Distribution Management 43(2), 148-166. https://doi.org/10.1108/ IJRDM-06-2013-0128

Venkatesh, V. \& Morris, M.G., 2000, 'Why don't men ever stop to ask for directions? Gender, social influence and their role in technology acceptance and usage behaviour', MIS Quarterly 24(1), 115-139.

Vijayasarathy, L.R., 2004, 'Predicting consumer intentions to use online shopping: The case for an augmented technology acceptance model', Information and Management Journal 41(2004), 747-762.

Wakama, A., 2017, Mobile shopping in South Africa, in IT News Africa, viewed 18 December 2019, from https://www.itnewsafrica.com/2017/06/mobileshopping-in-south-africa/.

Wiid, J. \& Diggines, C., 2013, Marketing research, 2nd edn., Juta, Cape Town.

Wu, W.Y., Quyen, P.T.P. \& Rivas, A.A.A., 2016, 'How e-servicescapes affect customer online shopping intention: The moderating effects of gender and online purchasing experience', Information Systems and E-Business Management 5(3) 689-715. https://doi.org/10.1007/s10257-016-0323-x

Yadav, R., Sharma, S.K. \& Tarhini, A., 2016, 'A multi-analytical approach to understand and predict the mobile commerce adoption', Journal of Enterprise Information Management 29(2), 222-237. 